Gimenes, L. U. '; Prestes, N. C. '; Moya, C. F.'; Porto, C.D. ${ }^{2}$; Rocha, N. S. ${ }^{2}$

\section{4 - Mesotelioma abdominal em cão. Relato de caso}

1- Departamento de Reprodução Animal e Radiologia Veterinária da Faculdade de Medicina Veterinária e Zootecnia da Universidade Estadual Paulista, Campus de Botucatu, Botucatu-SP

2-Departamento de Patologia Veterinária da Faculdade de Medicina Veterinária e Zootecnia da Universidade Estadual Paulista, Campus de Botucatu, Botucatu-SP

Os mesoteliomas são neoplasias primárias, de origem mesodérmica, que surgem em superficies serosas como a pleura, o pericárdio e o peritônio (SMITH \& HILL, 1989). São raramente encontrados em animais domésticos, porém há relatos na literatura de casos em bovinos, ovinos, eqüinos, felinos e caninos, sendo que nesta última espécie, os adultos são os mais freqüentemente acometidos, sem aparente predisposiçào racial (HEAD, 1990). Macroscopicamente este tipo de neoplasia apresenta múltiplos nódulos de tamanhos variados, com coloração variando de amarelada/ acinzentada a avermelhada, dependendo da presença de hemorragia e sua duração, com subseqüente formação de hemossiderina (COSTA et al., 2002; HEAD, 1990). A propagação se dá por via direta através de implantaçào, e dificilmente metástases ocorrem por via hematógena ou linfática (SMITH \& HILL, 1989). Microscopicamente são observados padrões celulares predominantemente mesenquimais, epiteliais ou mistos (PEREIRA et al., 2001; YOO et al., 2000). Os sinais clínicos apresentados por càes com mesotelioma são decorrentes da intensa exsudação oriunda da superficie tumoral ou obstrução da drenagem linfática, ocasionando alterações de acordo com o local onde está instalado. No saco pericárdico produz efusào e tamponamento cardíaco. No tórax, observa-se efusão pleural, dispnéia, abafamento de sons pulmonares, tosse e emaciação. Quando há o acometimento do peritônio este está associado à distensão abdominal progressiva e ascite (COSTA et al., 2002; PEREIRA et al., 2001; HEAD, 1990). O presente trabalho relata o caso de um animal da espécie canina, sem raça definida, fêmea, nove anos de idade, com 14,5 quilogramas, encaminhado ao Departamento de Reprodução Animal da FMVZ - UNESP - Botucatu, devido a suspeita de piometra. Pela anamnese, o paciente apresentava aumento abdominal progressivo há 20 dias, pseudociese há 1 mês, associada a secreção vaginal sanguinolenta e piúria. Havia histórico pregresso de uso freqüente de anticoncepcionais. Ao exame clínico verificou-se hipotermia, desidratação severa, palidez de mucosas e abdômen tenso e aumentado de volume. Os exames complementares realizados foram hemograma, hemogasometria e radiografia abdominal. No hemograma e hemogasometria, foram observados, respectivamente, anemia e hipoproteinemia severas e acidose metabólica. No exame radiográfico diagnosticou-se massa radiopaca ocupando toda cavidade abdominal, com deslocamento cranial de alças intestinais. Foi realizada laparotomia exploratória, onde encontrou-se grande massa aderida ao mesentério, porém sem alteraçòes em trato reprodutivo, sendo o animal submetido à eutanásia durante o procedimento cirúrgico e encaminhado posteriormente ao Serviço de Patologia Veterinária para exame necroscópico. Na necropsia observaram-se atelectasia pulmonar compressiva e estenose de cólon, além de edema subcutâneo em membros posteriores, cirrose hepática e nefrite crônica. A massa pesou quatro quilos, representando cerca de $36 \%$ da massa corpórea do animal. Apresentou-se aderida ao mesentério, sem envolvimento da serosa intestinal ou peritoneal e, ao corte, áreas de extensa necrose e outras de coloração esbranquiçada com consistência firme foram notadas. O diagnóstico diferencial para fibrossarcoma e lipossarcoma foi necessário, e no exame histopatólogico, observaram-se intenso pleomorfismo celular, áreas com células contendo citoplasma amplo e eosinofilico, semelhante aos carcinomas, e outras com células fusiformes e produção de colágeno organizando-se em padrào estoriforme, mimetizando os fibrossarcomas, achados estes compativeis com mesotelioma do tipo misto. $\mathrm{Na}$ literatura nào foram encontrados relatos de mesoteliomas em regiào mesentérica. 